\title{
Development of Realistic Mathematics Education (RME) Model Based on HOTS Problems for the Topic of Ratio
}

\author{
Rahmawati $^{1^{*}}$, Mayang Gadih Ranti ${ }^{2}$ \\ ${ }^{1,2}$ UIN Antasari Banjarmasin \\ *rahma282012@gmail.com
}

Received: May 2021. Accepted: June 2021. Published: July 2021.

\begin{abstract}
Learning using Realistic Mathematics Education is a breakthrough in mathematics learning. A difficulty in implementation of PMRI on learning is there are no adequate learning resources or learning media which facilitate PMRI Implementation on learning. This research is aim to develop a PMRI learning pack on ratio topic which consist of Model Book, Teacher's Book, Student's Book, Lesson Plan, Worksheets and Evaluation sheets. The product was developed using Higher Order Thinking Skills (HOTS) problems to support students ability to solve problems and develop student's thinking abillity. Development model used was Plomp Model. From research results we find that the product was valid, practice, and effective. Validation results show that the validation score was 4,19. The practically was obtained by the consistency of practically evaluation scores from expert and learning observation results. The effectiveness was obtained by four indicators, namely: 1) 80\% of 35 students gain high or very high score, 2) percentage average of students and teachers activities gain ideal tolerance time, 3) 92,5 \% of students give a positive response on learning, and 4) Teacher's capability to manage to learn good category.

Keywords: development, Realistic mathematics education, ratio
\end{abstract}

How to Cite: Rahmawati \& Ranti, M. G. (2021). Development of Realistic Mathematics Education (RME) Model Based on HOTS Problems for the Topic of Ratio. Journal of Medives: Journal of Mathematics Education IKIP Veteran Semarang, 5(2), 281-293. 


\section{PENDAHULUAN}

Matematika merupakan cabang ilmu yang yang mendasari ilmu-ilmu lainnya. Pentingnya mempelajari matematika menjadikan matematika menjadi ilmu pengetahuan yang dipelajari diberbagai jenjang pendidikan. Hal ini seperti tercantum dalam UU Sistem Pendidikan Nasional No. 20 Tahun 2003 Pasal 37 yang menyatakan matematika merupakan mata melajaran yang wajib diajarkan di kurikulum pendidikan dasar dan menengah.

Matematika sendiri memiliki karakteristik yang abstrak. Hudojo dalam (Hastratuddin, 2014) menyatakan bahwa matematika merupakan ide-ide abstrak yang diberi simbol-sombol itu tersusun secara hierarkis dan penalarannya deduktif, sehingga belajar matematika merupakan kegiatan mental yang tinggi. Matematika sering dianggap sebagai mata pelajaran yang sulit dikarenakan sifatnya yang abstrak tersebut. Akibatnya siswa kesulitan memahami konsep-konsep dalam matematika karena sifatnya yang abstrak. Hal ini seperti yang diungkapkan Jihad (2008) dalam (Novitasari, 2018) bahwa salah satu kendala dalam pembelajaran matematika adalah karakteristik matematika yang abstrak, selain masalah media, masalah siswa atau guru. Kendala ini membuat siswa menjadi kurang terlibat aktif dalam pembelajaran yang berakibat pada hasil belajar yang kurang.

Berbagai penelitian terdahulu mencoba mengungkap pentingnya mengaitkan matematika dengan kehidupan sehari-hari guna menjembatani konsep matematika yang abstrak dengan dunia nyata siswa. Freudental mem- berikan ungkapan 'Mathematics for life' and 'mathematics as a human activities' yang artinya matematika merupakan sebuah aktivitas kehidupan manusia yang dilakukan dalam kehidupan seharihari. Setiap aktivitas manusia tidak bisa terlepas dari matematika. (Widyastuti \& Pujiastuti, 2014). Pembelajaran matematika akan lebih bermakna jika dikaitkan dengan kehidupan sehari-hari.

Pentingnya mengaitkan pembelajaran matematika dengan kehidupan sehari-hari melahirkan berbagai pendekatan atau model pembelajaran yang menjadikan permasalahan dalam kehidupan sehari-hari sebagai pengantar atau stimulus di awal pembelajaran. Pembelajaran dalam matematika dikaitkan dengan hal-hal yang telah dialami sebelumnya oleh siswa atau yang berkaitan dengan masalah dalam kehidupan sehari-hari siswa.

Menurut (Masykur \& Fathani, 2007) pembelajaran akan lebih bermakna dan relevan apabila masalah yang diberikan adalah masalah-masalah kontekstual dan realistik, yaitu masalah yang sudah dikenal dan dekat dengan kehidupan siswa. Dengan demikian, masalah kontekstual dapat digunakan sebagai titik awal dalam pembelajaran matematika untuk membantu siswa mengembangkan pengertian terhadap konsep matematika yang dipelajari, menyusun strategi, dan menemukan sifat-sifat dalam matematika. Konsep matematika yang muncul dari masalah kontekstual merupakan salah satu ciri dari matematika realistik.

Salah satu pendekatan pembelajaran yang menggunakan masalah realistik dan kontekstual sebagai pengantar dalam 
pembelajaran matematika yaitu Pendidikan Matematika Realistik Indonesia (PMRI). PMRI merupakan inovasi dalam pendidikan matematika yang berasal dari Belanda yang dikenal dengan nama RME (Realistic Mathematics Education). RME dikembangkan oleh Freudenthal pada tahun 1971. PMRI adalah pendekatan pembelajaran yang bertitik tolak dari hal-hal yang "real" bagi siswa, menekankan "proses of doing mathematics", berdiskusi, berkolaborasi, berargumentasi dengan teman sekelas untuk menemukan sendiri dan pada akhirnya menggunakan matematika itu untuk menyelesaikan masalah baik secara individu maupun kelompok. (Widyastuti \& Pujiastuti, 2014).

Kelebihan PMRI adalah siswa lebih terlibat aktif dalam pembelajaran dan pembelajaran lebih bermakna bagi siswa karena apa yang mereka pelajari berasal dari hal-hal yang dekat dengan kehidupan mereka sehari-hari. PMRI sebagai inovasi pembelajaran di era New-Math menghadirkan proses matematitasi secara horizontal dan vertikal. Gravemaijer dalam (Hapipi, 2011) menyatakan bahwa

"Horizontal mathematization leads from the world of life to the world of symbols. In the world of life one lives, acts (and suffers); in the other. one symbols are shaped, reshaped, and manipulated, mechanically, comprehendingly, reflectingly: this is vertical mathematization."

Matematika horizontal merupakan proses transformasi hal-hal dalam kehidupan hanya ke dalam simbolsimbol, sedangkan matematitasi vertikal adalah proses pengolahan simbol-simbol itu itu sendiri, baik dalam bentuk pembentukan, pembentukan kembali, manipulasi secara mekanik, komprehensif dan refleksif di dalam matematika. Adanya dua proses ini membuat pembelajaran matematika menjadi lebih bermakna karena pembelajaran diawali dari hal-hal yang dekat dalam kehidupan sehari-hari. Masalah-masalah sehari-hari dapat digunakan sebagai sumber untuk memunculkan konsep, prinsip, algoritma, atau prosedur dalam matematika. Jadi pembelajaran tidak dimulai dengan definisi, teorema, dan diikuti contoh-contoh, tetapi siswa diajak untuk menemukan kembali konsep atau rumus melalui masalahmasalah riil.

Tiga komponen utama dalam PMRI yaitu (1) guided reinvention and progressive mathematizing, (2) didactical phenomenology, dan (3) selfdeveloped model mendorong siswa terlibat aktif dalam pembelajaran karena siswa mengkonstruksi sendiri pengetahuan melalui proses penemuan terbimbing berdasarkan hal-hal dari dunia nyata atau dari pengalaman yang mereka miliki, pembelajaran diawali dari masalah-masalah kontekstual dan siswa memformulasikan sendiri model-model yang akan digunakan untuk memecahkan masalah.

Selain itu, PMRI juga mempunyai lima karakteristik yang menjadi ciri khas PMRI, yaitu (1) menggunakan masalah konstektual, (2) menggunakan model, (3) menggunakan kontribusi siswa, (4) interkatif, dan (5) terkait dengan topik lainnya (intertwining). Apabila kelima karakteristik ini dapat diterapkan dengan 
baik dalam pembelajaran, maka tentunya akan menjadi alternatif pembelajaran yang mumpuni dalam rangka membuat pembelajaran matematika menjadi menarik, inovatif dan bermakna. Penggunaan konteks kehidupan seharihari akan sangat membantu mendekatkan materi yang akan dipelajari dengan kehidupan sehari-hari siswa.

Selain mencoba mendekatkan konten matematika dengan permasalahan dalam kehidupan sehari-hari, guna menunjang tuntutan zaman saat ini yaitu berkembangnya kemampuan berpikir dan kemampuan pemecahan masalah siswa. PMRI sebagai model pembelajaran menjadi kerangka acuan pembelajaran akan dipadukan dengan pengembangan soal-soal berbasis Higher Order Thinking Skills (HOTS).

Menurut (Chuseri et al., 2021) HOTS berkaitan dengan kemampuan untuk menyelesaikan permasalahan, berpikir kritis, dan kreatif. Lebih lanjut ditambahkan proses berpikir secara kritis dan kreatif dengan HOTS dapat mendorong siswa untuk bisa melakukan penalaran tingkat tinggi. Hal ini sesuai dengan tujuan pembelajaran matematika yaitu agar siswa memiliki kemampuan berpikir logis, analitis, sistematis, kritis dan kreatif. (Sukendra \& Fridayanthi, 2020).

Soal-soal HOTS disusun sedemikian rupa sehingga memancing siswa untuk berpikir lebih dalam menyelesaikan masalah. Menurut Kemendikbud dalam (Sari et al., 2020) soal-soal HOTS tidak hanya sekadar mengingat, menyatakan kembali dan merujuk tanpa melakukan pengolahan.
Soal-soal yang digunakan pada tes hasil belajar dirancang sedemikian rupa sehingga memancing siswa untuk berpikir lebih tinggi dalam menyelesaikan masalah. Penggunaan soal berbasis HOTS pada model pembelajaran PMRI akan menambah nilai plus tersendiri, yaitu selain menjadikan pembelajaran matematika menjadi lebih bermakna bagi siswa karena konten matematika didekatkan dengan kehidupan seharihari siswa, tetapi juga dapat mendorong berkembangnya kemampuan berpikir siswa dalam menyelesaikan masalah.

Akan tetapi, penerapan PMRI dalam pembelajaran matematika di kelas masih terkendala kemampuan guru dan siswa dalam menjalankan prinsip-prinsip dan karakteristik dari PMRI. Hal ini terutama kurang tersedianya media atau sumber belajar bagi guru dan siswa dalam pembelajaran menggunakan pendekatan PMRI. Guru-guru masih kesulitan menerapkan pembelajaran PMRI di kelas, sehingga komponenkomponen dan karakteristik-karakteristik PMRI belum sepenuhnya dapat diterapkan dengan sempurna dan baik. Mereka memerlukan acuan yang dapat dituangkan dalam menyusun langkahlangkah pembelajaran berbasis PMRI. Guru-guru juga masih kesulitan menyusun pembelajaran matematika berbasis PMRI.

Di sisi lain, siswa juga kesulitan menerapkan PMRI di kelas karena kurangnya sumber atau media belajar yang mendukung. Sumber atau media belajar yang tersedia di pasaran kurang mendukung siswa untuk melakukan proses penemuan berdasarkan masalahmasalah kontekstual. Padahal banyak 
sekali materi-materi dalam matematika yang dapat dikaitkan dengan kehidupan sehari-hari siswa.

Salah satu materi pada pembelajaran matematika yang penting dan menjadi dasar dalam pembelajaran matematika lainnya adalah materi perbandingan. Seperti yang diungkapkan Lamon (2006) dalam (Irfan \& Nusantara, 2018) bahwa pecahan dan perbandingan merupakan dua konsep yang penting dalam penalaran proporsi.

Lebih lanjut dalam penelitian (Irfan \& Nusantara, 2018), siswa mengalami kesulitan dalam menyelesaikan soal-soal pada materi perbandingan. $86 \%$ siswa mengalami kesalahan dalam menyelesaikan masalah perbandingan berbalik nilai, 28\% siswa mengalami kesalahan dalam menyelesaikan perbandingan senilai, dan $91 \%$ siswa mengalami kesalahan dalam dalam menyelesaikan masalah perbandingan senilai dan berbalik nilai pada solusi tunggal. Berdasarkan hasil wawancara dengan guru di salah satu sekolah yaitu SMPN 2 Depok, diperoleh hasil pemahaman konsep siswa pada kompetensi menyelesaikan soal cerita tentang perbandingan berbalik nilai masih rendah yaitu 57,52\%. PMRI merupakan salah satu alternatif yang cocok untuk pembelajaran materi perbandingan sesuai dengan yang dinyatakan Van de Walle (2008) dalam (Apriyani et al., 2017) bahwa salah satu cara untuk mengajarkan materi perbandingan dapat dilakukan dengan kegiatan eksplorasi. Kegiatan eksplorasi merupakan bagian yang penting dalam PMRI.
Oleh karena itu, mengingat pentingnya penerapan pembelajaran PMRI dalam matematika dan belum tersedianya media atau sumber belajar yang mendukung terhadap penerapan pembelajaran PMRI di kelas, khususnya dengan soal-soal berbasis HOTS, maka akan dilakukan Pengembangan Model Pembelajaran Matematika Realistik pada Materi Perbandingan di Kelas VII SMP. Kelebihan penelitian ini adalah produk yang dikembangkan merupakan perangkat lengkap yang dapat digunakan oleh guru maupun siswa dalam pembelajaran yang terdiri atas Buku Model, Buku Guru (BG), Buku Siswa (BS), RPP, Lembar Kerja Siswa (LKS) dan Tes Hasil Belajar (THB) disusun dengan menggunakan soal berbasis HOTS yang kesemuanya mendukung pembelajaran menggunakan pendekatan PMRI.

\section{METODE PENELITIAN}

Metode penelitian yang digunakan dalam penelitian ini adalah Research and Development ( $R \& D)$. Produk yang dikembangkan adalah buku Model, Buku Guru, Buku Siswa, RPP dan LKS. Kualitas Produk yang dikembangkan didasarkan pada Kriteria Nieeven, yaitu valid, praktis dan efektif.

Model pengembangan yang digunakan dalam penelitian ini mengacu pada model Plomp dengan memperhatikan tiga aspek kualitas produk yang dikemukakan Nieveen. Modifikasi yang dilakukan terhadap model Plomp yaitu pada fase tes, evaluasi, dan revisi menjadi validasi, uji coba, dan revisi. Alasan modifikasi pada fase ini adalah menyesuaikan dengan prosedur penilaian kualitas produk yang dikemukakan 
Nieveen. Sedangkan pada fase implementasi tidak dilaksanakan dalam penelitian ini, karena capaian hasil penelitian pengembangan ini tidak langsung disebarluaskan untuk dipakai.

Prosedur pengembangan model pembelajaran dalam penelitian ini terdiri dari empat tahapan, yaitu (1) fase investigasi awal, (2) fase perancangan, (3) fase realisasi, dan (4) fase tes, evaluasi, dan revisi. Pada fase awal dilakukan kegiatan pra-survei untuk menghimpun informasi tentang permasalahan pembelajaran yang ada baik terhadap model pembelajaran yang digunakan dan perangkat pembelajaran yang sudah digunakan. Kemudian tahap berikutnya dilakukan perancangan model pembelajaran, meliputi sintakssintaks pembelajaran PMRI serta merancang perangkat pembelajaran yang terdiri atas Buku Model, Buku Guru (BG), Buku Siswa (BS), RPP, Lembar Kerja Siswa (LKS), dan Tes Hasil Belajar (THB).

Tahap berikutnya adalah tahap realisasi dimana pada tahap ini hasil yang diharapkan adalah draft Prototipe 1 yaitu, model pembelajaran matematika realistik Indonesia, perangkat pembelajaran, dan instrumen-instrumen untuk menjaring data kevalidan, kepraktisan, dan keefektifan model pembelajaran matematika realistik Indonesia. Tahap terakhir yang dilakukan adalah fase validasi, uji coba dan revisi dimana pada kegiatan ini dilakukan permintaan pertimbangan/penilaian kepada para ahli dan praktisi terhadap draft model pembelajaran matematika realistik yang dihasilkan dan instrumen penelitian.
Uji coba produk dilakukan di SMPN 2 Depok, dengan subjek uji coba yaitu siswa kelas VII yang berjumlah 35 siswa dan satu orang guru matematika. Uji coba dilakukan dalam dua tahap, yaitu validasi perangkat pembelajaran dari para ahli dan uji coba lapangan. Instrumen penelitian yang digunakan dalam penelitian ini adalah: (1) lembar validasi, (2) lembar penilaian ahli dan praktisi tentang keterlaksanaan dan keefektivan model, (3) angket respon siswa dan guru terhadap komponen dan kegiatan pembelajaran, dan (4) tes hasil belajar.

Teknik analisis data yang digunakan adalah mengkonversi data kuantitatif menjadi data kualitatif skala lima. Hasil penilaian yang diperoleh dari para ahli, guru dan siswa dikonversi menggunakan Tabel 1. Berdasarkan Tabel 1 diperoleh kriteria-kriteria kualifikasi untuk masing-masing kriteria kualitas produk yang dihasilkan ditinjau dari kevalidan, kepraktisan dan keefektifan.

Tabel 1. Konversi Data Kuantitatif Menjadi Data Kualitatif Menggunakan Skala Lima

\begin{tabular}{ccc}
\hline Nilai & Interval Skor & Kategori \\
\hline A & $\bar{X}>\bar{X}_{l}+1,8 S B i$ & Sangat Baik \\
B & $\bar{X}_{l}+0,6 S B i<\bar{X} \leq \bar{X}_{l}+1,8 S B i$ & Baik \\
$\mathrm{C}$ & $\bar{X}_{l}-0,6 S B i<\bar{X} \leq \bar{X}_{l}+0,6 S B i$ & Cukup \\
$\mathrm{D}$ & $\bar{X}_{l}-1,8 S B i<\bar{X} \leq \bar{X}_{l}+0,6 S B i$ & Kurang \\
$\mathrm{E}$ & $\bar{X} \leq \bar{X}_{l}-1,8 S B i$ & Sangat Kurang \\
\hline Keterangan: & \\
$\bar{X}_{l} \quad=$ & Rerata skor ideal = $1 / 2 \quad$ (skor maksimal \\
& ideal + skor minimal ideal) \\
$S B i=$ & Simpangan baku Ideal = $1 / 6 \quad$ (skor \\
& maksimal ideal - skor minimum Ideal) \\
$\bar{X}$ & $=$ & Skor Aktual
\end{tabular}

Untuk kevalidan perangkat pembelajaran dilihat dari hasil penilaian para ahli atau validator. Tabel 2 menunjukkan 
kriteria kualifikasi kevalidan perangkat yang dihasilkan berdarakan penilaian para ahli.

Tabel 2. Tingkat Kevalidan Model dan Perangkat Pembelajaran Matematika Realistik Indonesia

\begin{tabular}{ccc}
\hline Interval & Nilai & Kategori \\
\hline$V a>4,21$ & A & Sangat Valid \\
$3,40<V a \leq 4,21$ & B & Valid \\
$2,60<V a \leq 3,40$ & C & Cukup Valid \\
$1,79<V a \leq 2,60$ & D & Kurang Valid \\
$V a \leq 1,79$ & E & Tidak Valid \\
\hline
\end{tabular}

Keterangan: $V a=$ nilai validitas

Berikutnya, kriteria kepraktisan dilihat dari hasil penilaian ahli dan observasi keterlaksanaan pembelajaran di kelas. Tabel 3, 4, dan 5 menunjukkan kriteria keterlaksanaan pembelajaran di kelas berdasarkan hasil penilaian ahli dan observasi.

Tabel 3. Tingkat Keterlaksanaan Model Berdasarkan Penilaian Ahli/ Praktisi

\begin{tabular}{ccc}
\hline Interval & Nilai & Kategori \\
\hline $\mathrm{I}-\mathrm{P}>4,21$ & $\mathrm{~A}$ & Sangat tinggi \\
$3,40<\mathrm{I}-\mathrm{P} \leq 4,21$ & $\mathrm{~B}$ & tinggi \\
$2,60<\mathrm{I}-\mathrm{P} \leq 3,40$ & $\mathrm{C}$ & Cukup \\
$1,79<\mathrm{I}-\mathrm{P} \leq 2,60$ & $\mathrm{D}$ & Rendah \\
$\mathrm{I}-\mathrm{P} \leq 1,79$ & $\mathrm{E}$ & Sangat rendah \\
\hline
\end{tabular}

Keterangan:

$I P=$ intended-perceived model pembelajaran

Tabel 4. Tingkat Keterlaksanaan Model Berdasarkan Penilaian Ahli/ Praktisi

\begin{tabular}{ccc}
\hline $\mathrm{e}$ & Nilai & Kategori \\
\hline $\mathrm{I}-\mathrm{P}>4,21$ & $\mathrm{~A}$ & Sangat tinggi \\
$3,40<\mathrm{I}-\mathrm{P} \leq 4,21$ & $\mathrm{~B}$ & tinggi \\
$2,60<\mathrm{I}-\mathrm{P} \leq 3,40$ & $\mathrm{C}$ & Cukup \\
$1,79<\mathrm{I}-\mathrm{P} \leq 2,60$ & $\mathrm{D}$ & Rendah \\
$\mathrm{I}-\mathrm{P} \leq 1,79$ & $\mathrm{E}$ & Sangat rendah \\
\hline
\end{tabular}

Keterangan:

IP = intended-perceived model pembelajaran
Tabel 5. Tingkat Keterlaksanaan Model

Berdasarkan Pengamatan Pembelajaran

\begin{tabular}{ccc}
\hline Interval & Nilai & Kategori \\
\hline I $-0>4,21$ & A & Sangat tinggi \\
$3,40<\mathrm{I}-\mathrm{O} \leq 4,21$ & $\mathrm{~B}$ & tinggi \\
$2,60<\mathrm{I}-\mathrm{O} \leq 3,40$ & $\mathrm{C}$ & Cukup \\
$1,79<\mathrm{I}-\mathrm{O} \leq 2,60$ & $\mathrm{D}$ & Rendah \\
$\mathrm{I}-\mathrm{O} \leq 1,79$ & $\mathrm{E}$ & Sangat rendah \\
\hline
\end{tabular}

Keterangan:

$I O=$ intended-operational model pembelajaran

Untuk keefektifan dilihat dari hasil tes belajar siswa. Pembelajaran dikatakan efektif jika $80 \%$ dari siswa subjek belajar memperoleh nilai pada kategori minimal tinggi. Tabel 6 menjelaskan kategori Hasil Belajar Siswa (HBS).

Tabel 6. Interval Skor Hasil Belajar Siswa

\begin{tabular}{cc}
\hline Interval Skor HBS & Kategori \\
\hline $0 \leq H B S<9,7$ & Sangat Rendah \\
$9,7 \leq H B S<19,4$ & Rendah \\
$19,4 \leq H B S<29,1$ & Sedang \\
$29,1 \leq H B S<38,8$ & Tinggi \\
$38,8 \leq H B S<48,5$ & Sangat Tinggi \\
\hline
\end{tabular}

Secara keseluruhan, model pembelajaran matematika realistik Indonesia dinyatakan memenuhi kriteria keefektifan, jika ke empat indikator mencapai kriteria yang ditetapkan, yaitu: (a) minimal $80 \%$ siswa mencapai hasil belajar sedang atau tinggi, (b) aktivitas siswa dan guru selama pembelajaran telah mencapai persentase waktu ideal yang ditetapkan, (c) minimal 80\% siswa dari banyak subjek yang diteliti (untuk setiap uji coba) memberikan respons yang positif terhadap komponen kegiatan pembelajaran, (d) kemampuan guru mengelola pembelajaran mencapai kriteria minimal "cukup", dan (e) aktivitas siswa dan guru dinilai 
berdasarkan presentase waktu ideal yang ditetapkan.

\section{HASIL DAN PEMBAHASAN}

Berdasarkan hasil-hasil yang diperoleh sesuai dengan pelaksanaan prosedur-prosedur penelitan, diperoleh hasil-hasil sebagai berikut.

\section{Fase Investigasi Awal}

Pada tahap ini diperoleh hasil berdasarkan observasi dan wawancara di SMPN 2 Depok bahwa pembelajaran yang ada saat ini masih berpusat pada guru. Guru masih mendominasi pembelajaran serta guru masih kurang mengaitkan materi-materi pembelajaran yang akan dipelajari dengan pengetahuan-pengetahuan sebelumnya yang sudah dimiliki oleh siswa. Siswa masih pasif dimana kegiatan di kelas oleh siswa masih hanya seputar mendengarkan penjelasan guru, mencatat dan mengerjakan soal.

Hal penting lainnya adalah temuan bahwa selama ini guru menggunakan model pembelajaran yang kurang relevan dengan perkembangan karakteristik siswa. Guru belum menggunakan model-model pembelajaran yang inovatif dan mendorong siswa terlibat aktif dalam pembelajaran. Temuan lain yang tidak kalah penting adalah belum tersedianya media atau perangkat pembelajaran yang mendukung siswa untuk mengaitkan materi yang akan dipelajari dengan peristiwa-peristiwa yang terjadi dilingkungan sekitar mereka, sehingga pembelajaran menjadi kurang bermakna bagi siswa.

\section{Fase Perancangan}

Pada fase ini dirancang model pembelajaran matematika realistik Indonesia, perangkat pembelajaran dan instrumen penelitian yang akan digunakan. Pada fase ini diperoleh rancangan awal buku model, buku guru, buku siswa, RPP, LKS dan tes hasil belajar pada materi perbandingan.

\section{Fase Realisasi}

Hasil-hasil yang diperoleh pada fase investigasi awal dan fase perancangan, selanjutnya direfleksi dan dicermati kembali untuk diarahkan pada penyusunan model atau realisasi model pembelajaran matematika realistik Indonesia bersama dengan perangkat pembelajaran dan instrumen.

Produk yang dihasilkan pada fase ini mencakup: (1) model pembelajaran matematika realistik Indonesia berupa buku model, (2) perangkat pembelajaran (RPP, BG, BS, LKS, THB), dan (3) instrumen-instrumen penelitian. Produk ini secara keseluruhan disebut prototype awal (prototype -1 model pembelajaran matematika realistik Indonesia). Tes Hasil Belajar disini disusun dengan berbasis HOTS pada materi perbandingan senilai dan berbalik nilai.

\section{Fase Tes, Evaluasi, dan Revisi}

Pada fase ini dilakukan validasi prototipe awal oleh ahli materi atau praktisi untuk mengetahui kevalidan produk yang dikembangkan. Hasil validasi yang diperoleh dari para ahli untuk masing-masing buku model, perangkat pembelajaran (RPP, BG, BS, LKS, THB) dapat dilihat pada Tabel 7 hingga Tabel 12. 
Tabel 7. Data Hasil Validasi Buku Model Pembelajaran

\begin{tabular}{lccc}
\hline \multirow{1}{*}{ Komponen } & \multicolumn{3}{c}{ Rata-Rata Penilaian } \\
& 1 & 2 & 3 \\
\hline Teori Pendukung & 4,00 & 4,00 & 4,00 \\
Sintaks & 4,57 & 4,14 & 4,71 \\
Sistem Sosial & 4,33 & 4,14 & 4,71 \\
Prinsip reaksi & 4,50 & 3,67 & 4 \\
Sistem pendukung & 4,50 & 4,50 & 4,50 \\
Dampak instruksional & 3,86 & 3,71 & 3,86 \\
Pelaksanaan Model & & & \\
$\quad$ Pembelajaran & 3,67 & 3,67 & 3,67 \\
\hline
\end{tabular}

Tabel 9. Data Hasil Validasi RPP

\begin{tabular}{lccc}
\hline \multirow{1}{*}{ Komponen } & \multicolumn{3}{c}{ Rata-Rata Penilaian } \\
& 1 & 2 & 3 \\
\hline Format RPP & 4,00 & 4,00 & 4,00 \\
Tujuan & 3,75 & 3,50 & 4,00 \\
Materi Prasyarat & 4,00 & 4,00 & 4,00 \\
Materi Pelajaran & 4,50 & 4,25 & 4,00 \\
Penilaian & 4,00 & 3,00 & 4,00 \\
Kegiatan Pembelajaran & 4,50 & 4,00 & 4,00 \\
Bahasa dan Tulisan & 4,25 & 4,00 & 4,50 \\
Alokasi Waktu & 4,00 & 4,00 & 4,00 \\
Penutup & 4,00 & 4,00 & 4,00 \\
\hline
\end{tabular}

Tabel 10. Data Hasil Validasi Buku Guru

\begin{tabular}{lccc}
\hline \multirow{1}{*}{ Komponen } & \multicolumn{3}{c}{ Rata-rata Penilaian } \\
& 1 & 2 & 3 \\
\hline Komponen Buku & 4,00 & 4,17 & 4,33 \\
Format Buku & 4,29 & 4,00 & 4,00 \\
Isi Buku & 4,17 & 4,33 & 4,50 \\
Bahasa dan Tulisan & 4,25 & 4,75 & 4,75 \\
Ilustrasi Tata Letak Tabel, & & & \\
$\quad$ Gambar dan Grafik & 3,50 & 4,25 & 4,00 \\
\hline
\end{tabular}

Tabel 11. Data Hasil Validasi Buku Siswa

\begin{tabular}{lccc}
\hline \multirow{1}{*}{ Komponen } & \multicolumn{3}{c}{ Rata-Rata Penilaian } \\
& 1 & 2 & 3 \\
\hline Format Buku & 4,43 & 4,00 & 4,43 \\
Isi Buku & 4,33 & 4,17 & 4,00 \\
Bahasa dan Tulisan & 4,60 & 4,20 & 4,20 \\
Ilustrasi Tata Letak Tabel, & & & \\
$\quad$ Gambar dan Grafik & 4,00 & 4,25 & 4,50 \\
\hline
\end{tabular}

Tabel 12. Data Hasil Validasi Lembar Kegiatan Siswa (LKS)

\begin{tabular}{lccc}
\hline \multirow{1}{*}{ Komponen } & \multicolumn{3}{c}{ Rata-Rata Penilaian } \\
& 1 & 2 & 3 \\
\hline Format LKS & 4,29 & 4,14 & 4,29 \\
Isi LKS & 4,17 & 4,33 & 4,50 \\
Bahasa dan Tulisan & 4,20 & 4,00 & 4,40 \\
Ilustrasi Tata Letak & & & \\
$\quad$ Tabel, Gambar dan & & & \\
$\quad$ Grafik & 3,75 & 4,50 & 4,50 \\
\hline
\end{tabular}

Berdasarkan hasil validasi perangkat diperoleh bahwa produk-produk yang dihasilkan, baik buku model, maupun perangkat pembelajaran yang meliputi RPP, Buku Siswa, Buku Guru, LKS dan THB termasuk dalam kategori valid. Rata-rata hasil validasi isi dan konstruk buku model masing-masing adalah 4,12 dan 4,29, sedangkan ratarata nilai validasi perangkat pembelajaran adalah 4,19. Beberapa bagian dari perangkat pembelajaran tetap direvisi sesuai dari masukan para ahli.

Untuk kepraktisan pembelajaran diperoleh dari hasil analisis data kepraktisan model menurut ahli/praktisi dan keterlaksanaan pembelajaran. Menurut ahli/praktisi model PMRI yang dikembangkan berada pada kategori tinggi, dan hasil pelaksanaan pembelajaran berada pada kategori sedang. Adanya kekonsistenan antara penilaian ahli/praktisi dengan keterlaksanaan model menunjukkan model yang dikembagkan telah memenuhi kriteria kepraktisan. Tabel 13 dan Tabel 14 adalah hasil analisis kepraktisan model menurut para ahli/praktisi per indikator penilaian. 
Tabel 13. Hasil Analisis Data Kepraktisan

\begin{tabular}{lcc}
\multicolumn{3}{c}{ Model Menurut Para Ahli } \\
\hline \multicolumn{1}{c}{ Indikator Penilaian } & $\begin{array}{c}\text { Rata- } \\
\text { Rata }\end{array}$ & Kategori \\
\hline $\begin{array}{l}\text { Secara teoritis, } \\
\text { kemungkinan guru mampu } \\
\text { melaksanakan sintaks } \\
\text { pembelajaran tersebut }\end{array}$ & 4,33 & $\begin{array}{l}\text { Sangat } \\
\text { Tinggi }\end{array}$ \\
$\begin{array}{l}\text { Secara teoritis, } \\
\text { kemungkinan guru mampu } \\
\text { mewujudkan sistem sosial } \\
\text { pembelajaran tersebut }\end{array}$ & 4,33 & Sangat \\
$\begin{array}{l}\text { Secara teoritis, } \\
\text { kemungkinan guru mampu } \\
\text { melaksanakan prinsip } \\
\text { reaksi pengelolaan } \\
\text { pembelajaran tersebut }\end{array}$ & 3,67 & Tinggi \\
\begin{tabular}{l} 
Rata-rata penilaian \\
\hline
\end{tabular} & 4,11 & Tinggi \\
\hline
\end{tabular}

Tabel 14. Hasil Analisis Data Keterlaksanaan

\begin{tabular}{|c|c|c|}
\hline \multicolumn{3}{|c|}{ Pembelajaran } \\
\hline $\begin{array}{c}\text { Aspek yang } \\
\text { Dinilai }\end{array}$ & $\begin{array}{l}\text { Rata- } \\
\text { Rata }\end{array}$ & $\begin{array}{c}\text { Tingkat } \\
\text { Keterlaksanaan }\end{array}$ \\
\hline Sintaks & 3,22 & Sedang \\
\hline Sistem Sosial & 3,54 & Sedang \\
\hline Prinsip Reaksi & 3,98 & Sedang \\
\hline Rata-rata & 3,58 & Sedang \\
\hline
\end{tabular}

Untuk keefektivan pembelajaran, diperoleh data-data sesuai dengan indikator keefektivan yang ditetapkan, yaitu: (1) data hasil belajar siswa menunjukkan yaitu $80 \%$ dari 35 orang siswa yang mengikuti tes mencapai tingkat hasil belajar tinggi dan sangat tinggi, (2) rerata presentase waktu aktivitas siswa dan guru telah memenuhi batas toleransi waktu ideal yang ditetapkan, (3) 92,5\% siswa memberi respon positif terhadap PMRI, dan (4) kemampuan guru mengelola pembelajaran termasuk kategori Baik.

Beberapa bagian yang direvisi dari perangkat pembelajaran ini dapat dilihat pada Tabel 15.
Tabel 15. Revisi Produk

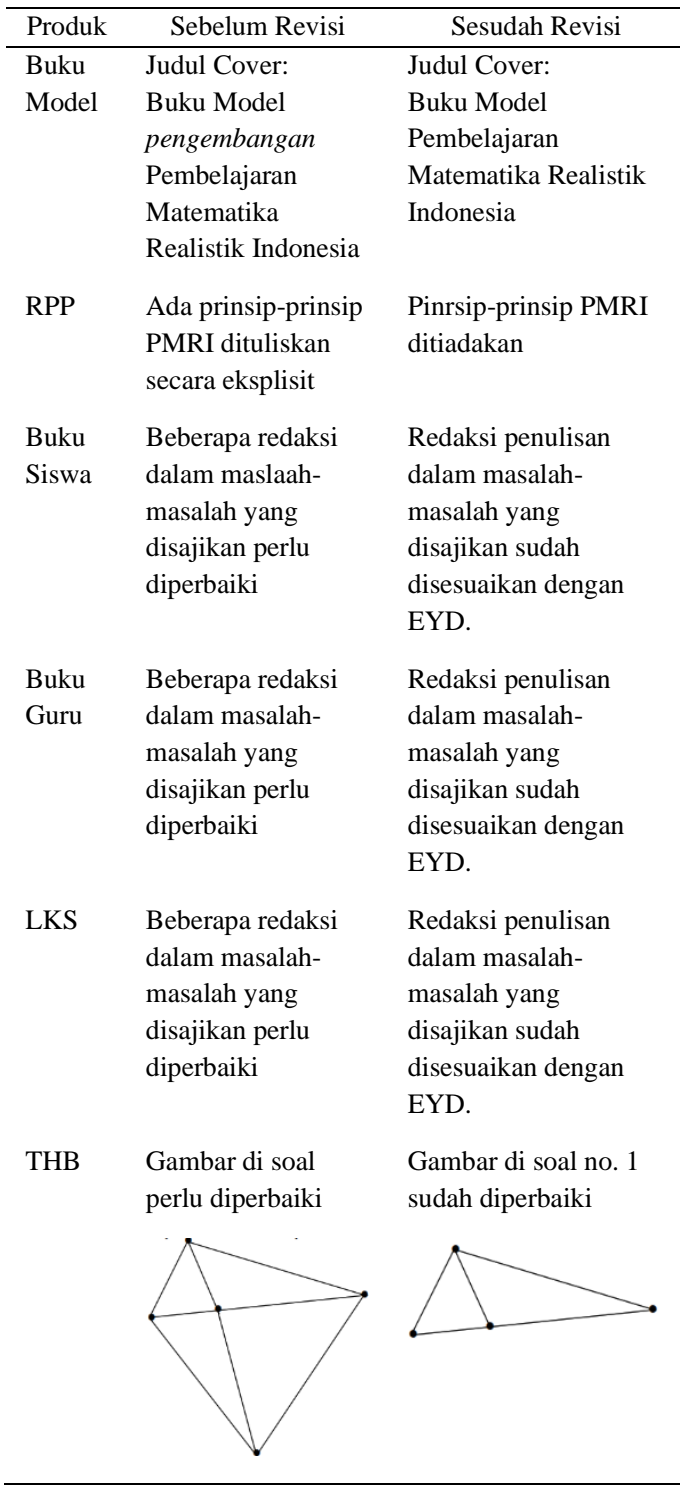

Berdasarkan hasil penelitian diperoleh bahwa pembelajaran dengan menggunakan pendekatan PMRI dapat berdampak positif bagi pembelajaran. Hal ini dapat dilihat dari hasil belajar yang diperoleh yaitu $80 \%$ siswa mencapai hasil minimal kategori sedang. Penggunaan konteks-konteks dalam kehidupan sehari-hari ternyata efektif membuat siswa menjadi lebih aktif dan semangat dalam pembelajaran. Hal ini sesuai dengan yang diungkapkan (Kadir \& Masi, 2014) bahwa penggunaan 
masalah kontekstual sangat menarik dan dapat memancing kemampuan komunikasi siswa untuk berinteraksi dengan siswa lainnya.

Selain itu, jika dilihat dari aktivitas siswa dan guru, pembelajaran dengan PMRI juga dapat dikatakan efektif. Berdasarkan aktivitas siswa diperoleh rata-rata aktivitas pada pertemuan I, II, III dan IV telah berada pada batas toleransi waktu ideal yang ditetapkan. Minimal 7 dari 9 aktivitas berada bada batas toleransi waktu ideal yang ditetapkan. Ini berarti siswa tidak lagi bersifat pasif menerima pengetahuan dari guru tetapi siswa aktif mengkonstruksi secara individu, bekerja sama menganalisis pemecahan masalah, berdiskusi baik dalam kelompok maupun antar kelompok dan mempresentasikan hasil konstruksi pengetahuan mereka di depan kelas. PMRI dapat membuat siswa menjadi lebih terlibat aktif dalam pembelajaran. Hal ini sesuai dengan hasil penelitian (Nugraheni, 2013) yaitu bahwa pembelajaran dengan PMRI berpengaruh positif terhadap aktivitas siswa.

Ditinjau dari aktivitas guru diperoleh bahwa penerapan model pembelajaran matematika realistik Indonesia cukup efektif mengubah perilaku mengajar guru yang selama ini terlalu mendominasi aktivitas kelas. Kebiasaan guru memberi informasi sebanyak-banyaknya kepada siswa berubah menjadi guru sebagai fasilitator, motivator, dan membimbing siswa dan membantu siswa dengan bantuan terbatas memecahkan masalah, mendorong siswa bekerjasama menyelesaikan tugas.
Respon siswa terhadap pembelajaran PMRI juga memberikan respon yang positif. Hal ini terlihat dari hasil respon siswa yatu sebanyak senang $92,59 \%$, berminat $100 \%$, dan tertarik 95,24\% terhadap komponen dan kegiatan pembelajaran. Pembelajaran dengan menggunakan PMRI dapat membuat siswa menjadi lebih termotivasi dalam pembelajaran. Hal ini sesuai dengan penelitian (Muzaini, 2018) yaitu bahwa menurut siswa pembelajaran matematika menggunakan PMRI lebih seru, lebih santai, mengasyikkan, menghadirkan pengalaman baru, kerjasama dan keberanian para siswa.

Penggunaan soal HOTS juga mendorong siswa untuk berpikir lebih dalam dan terlatih menyelesaikan masalah yang berkaitan dengan kehidupan sehari-hari menggunakan konsep perbandingan. Penggunaan soal-soal seperti ini sebelumnya sangat jarang didapatkan sebelumnya. Kebanyakan soal-soal yang diberikan guru sebelumnya hanya berisi aturan penggunaan rumus dan hafalan. Soal-soal HOTS digunakan untuk mendorong siswa memiliki kemampuan berpikir tingkat tinggi sesuai dengan pendapat Widodo \& Kardawati (2013) dalam (Wulandari et al., 2020) yang menyatakan Soal HOTS dapat meningkatkan pengetahuan dan keterampilan siswa.

\section{PENUTUP}

Penelitian ini menghasilkan produk berupa buku model, buku guru (BG), buku siswa (BS), Rencana Pelaksanaan Pembelajaran (RPP), Lembar Kegiatan Siswa (LKS) dan Tes Hasil Belajar 
(THB) barbasis HOTS untuk pembelajaran matematika menggunakan PMRI pada materi perbandingan. Pengembangan dilakukan melalui model pengembangan Model Plomp dengan tahap-tahap investigasi awal, perancangan, realisasi, dan tes, evaluasi, dan revisi. Produk yang dihasilkan memenuhi kriteria valid, praktis dan efektif.

Berdasarkan hasil penelitian juga diperoleh bahwa pembelajaran dengan PMRI berbasis soal HOTS nyatanya dapat membuat pembelajaran menjadi efektif karena dapat membuat siswa menjadi lebih terlibat aktif dalam pembelajaran sehingga mendorong berkembangnya kemampuan berpikir siswa dalam menyelesaikan masalah. sebaliknya guru dapat mengurangi dominasi dalam permbelajaran. Respon siswa yang baik juga menunjukkan bahwa PMRI dapat diterima oleh siswa sebagai sesuatu yang menyenangkan dalam pembelajaran matematika.

Saran untuk peneliti yang lain dapat mengembangkan perangkat pembelajaran PMRI berbasis HOTS untuk materi yang lain, serta dapat mengembangkan sampai pada tahap menyebarluaskan.

\section{DAFTAR PUSTAKA}

Apriyani, R., Somakim, -, \& Darmawijoyo, -. (2017). Developing Teaching Material of Direct Proportion Based on Agricultural Context. Jurnal Kependidikan: Penelitian Inovasi Pembelajaran, 1(1), 38-49. https://doi.org/10.21831/jk.v1i1.9 710

Chuseri, A., Anjarini, T., \& Purwoko, R. Y. (2021). Pengembangan Modul
Matematika Berbasis Realistik Terintegrasi Higher Order Thinking Skills (Hots) Pada Materi Bangun Ruang. Alifmatika: Jurnal Pendidikan Dan Pembelajaran Matematika, 3(1), 18-31. https://doi.org/10.35316/alifmatik a.2021.v3i1.18-31

Hapipi. (2011). Pendidikan Matematika Realistik (PMR) Sebagai Basis Pembelajaran Matematika. Beta, 4(1), 1-13.

Harta, J. (2017). Pengembangan Soal Esai Berbasis HOTS Untuk Menyelidiki Keterampilan Pemecahan Masalah Siswa SMA. Jurnal Penelitian. https://www.ejournal.usd.ac.id/index.php/JP/arti cle/view/896

Hastratuddin. (2014). Pembelajaran Matematika Sekarang dan yang akan Datang Berbasis Karakter. Didaktik Matematika, 1(2), 30-42. https://doi.org/10.24815/jdm.v1i2. 2059

Irfan, M., \& Nusantara, T. (2018). Why Did the Students Make Mistakes in Solving Direct and Inverse Proportion Problem? International Journal of Insights for Mathematics Teaching, 1(1), 25-34.

Kadir, \& Masi, L. (2014). Penggunaan Konteks dan Pengetahuan Awal Matematika dalam Pembelajaran Keterampilan Berpikir Kreatif Siswa Using Context and Mathematical Prior Knowledge in Learning Students ' Creativity Thinking Skills. Jurnal Pendidikan Matematika, 5(1), 5266.

Masykur, M., \& Fathani, A. H. (2007). Mathematical Intelligence: Cara Cerdas Melatih Otak dan Menanggulangi Kesulitan Belajar. 
Ar-ruzz Media.

Muzaini, M. (2018). Pendekatan Matematika Realistik Untuk Meningkatkan Hasil Belajar Matematis Siswa: Suatu Eksperimen pada Salah Satu Sekolah di Kabupaten Gowa Sulawesi Selatan. Proximal: Jurnal Penelitian Matematika Dan Pendidikan Matematika, 1(1), 5161.

Novitasari, D. (2018). Pengaruh Penggunaan Multimedia Interaktif Terhadap Kemampuan Pemahaman Konsep Matematis Siswa. Jurnal Pendidikan Matematikan \& Matematika, 51(1), 51.

Nugraheni, E. A. (2013). Pengaruh Pendekatan PMRI terhadap Aktivitas dan Pemahaman Konsep Matematika Siswa SMP. Pythagoras: Jurnal Pendidikan Matematika, 8(1), 101-108-108. https://doi.org/10.21831/pg.v8i1.8 498
Sari, I. T. S., Adisel, \& Syafri, F. S. (2020). Pengembangan Soal Matematika Berbasis Higher Order Thinking Skills (HOTS) Integrasi Kebangsaan Pada Siswa. Jurnal Pendidikan Matematika: Judika Education, 3(2), 109-120.

Sukendra, I. K., \& Fridayanthi, P. D. (2020). Pengembangan Bahan Ajar Dengan Pendidikan Matematika Realistik Berorientasi Pada Soal Hots Pada Era Revolusi Industri 4.0 Di Sma.

Widyastuti, N. S., \& Pujiastuti, P. (2014). Pengaruh Pendidikan Matematika Realistik Indonesia (PMRI) terhadap Pemahaman Konsep dan Berpikir Logis Siswa. Prima Edukasia, 2(2), 183-193.

Wulandari, S., Hajidin, H., \& Duskri, M. (2020). Pengembangan Soal Higher Order Thinking Skills (HOTS) pada Materi Aljabar di Sekolah Menengah Pertama. Jurnal Didaktik Matematika, 7(2), 200-220.

https://doi.org/10.24815/jdm.v7i2. 17774 